\title{
SOLUTION-FOCUSED BRIEF COUNSELING AND ABC MANIPULATION TECHNIQUE IN SELF-CONTROL TRAINING TO REDUCE AGGRESSIVE BEHAVIOUR
}

\author{
I Ketut Gading ${ }^{1}$, Siti Aishah Hassan ${ }^{2}$, Abu Yazid Abu Bakar ${ }^{3}$, Kade Sathya Gita Rismawan ${ }^{1}$ \\ ${ }^{1}$ Universitas Pendidikan Ganesha, Bali, Indonesia \\ ${ }^{2}$ Universitas Putra Malaysia, Selangor, Malaysia \\ ${ }^{3}$ Universitas Kebangsaan Malaysia, Selangor, Malaysia \\ *e-mail: iketutgading@undiksha.ac.id
}

\begin{abstract}
Aggressive behaviours in the society have been very alarming, including among high school students. To reduce aggressive behaviours, the main effort is to increase self-control. This study is aimed at describing the differences between the effectiveness of solution-focused brief counseling (SFBC) and Self-Control Training with the Antecedent-Behavioral-Consequence (ABC) manipulation technique to reduce students' aggressive behavior tendencies. The study is quasi-experimental research with a pretest-posttest control group design. The population of the study consists of 563 students. The sample selected by the simple random sampling technique amounts to 60 students. The data collection method of the study is a non-test technique. The instrument used for data collection is the Aggression Questionnaire (AQ) with 25 statement items. The data are analyzed using ANOVA test. The ANOVA test results show an $F$ value of 348.300 with a significance value of 0.000 ( $\mathrm{Sig}<0.05$ ); so, it can be interpreted that both solution-focused brief counseling (SFBC) and the Self-Control Training with the Antecedent-Behavioral-Consequence $(\mathrm{ABC})$ are effective in reducing aggressive behaviors. However, the ABC selfcontrol training model is found to be more effective. Therefore, guidance and counseling teachers are expected to continue working on self-control training for children, through the $\mathrm{ABC}$ self-control training model.
\end{abstract}

Keywords: self-control training, solution-focused brief counseling, antecedent-behavioral-consequence model, aggressive behavior

\section{SOLUTION-FOCUSED BRIEF COUNSELING DAN TEKNIK MANIPULASI ABC DALAM SELF-CONTROL TRAINING UNTUK MEREDUKSI PERILAKU AGRESIF}

\begin{abstract}
Abstrak: Fenomena perilaku agresif di masyarakat sangat memprihatinkan termasuk oleh siswa SMA. Untuk mengurangi perilaku agresif, upaya utama yang dilakukan adalah meningkatkan pengendalian diri karena hal itu bisa menjadi kunci untuk meredamnya. Penelitian ini bertujuan untuk mendeskripsikan perbedaan efektivitas solution-focused brief counseling (Solution-Focused Brief Counseling) dan Self-Control Training dengan teknik manipulasi Anteseden-Behavioral-Consequence (ABC) untuk mereduksi kecenderungan perilaku agresif siswa SMA. Penelitian ini merupakan penelitian eksperimen semu dengan pretestt-posttest control group design. Populasi penelitian berjumlah 563 orang, sedangkan sampel yang dipilih dengan teknik simple random sampling berjumlah 60 orang. Metode pengumpulan data adalah metode nontes. Instrumen yang digunakan adalah Aggression Questionnaire sebanyak 25 butir pernyataan. Data yang diperoleh dianalisis menggunakan uji anava dan uji t. Hasil uji anava menunjukkan nilai F sebesar 348.300 dengan nilai signifikansi sebesar 0.000 ( $\mathrm{Sig}<0.05$ ), sehingga dapat diinterpetasikan bahwa solution-focused brief counseling dan Self-Control Training teknik ABC efektif mereduksi perilaku agresif, tetapi hasil uji t menunjukkan Self-Control Training dengan teknik $\mathrm{ABC}$ lebih efektif. Oleh karena itu, guru bimbingan konseling diharapkan terus mengupayakan untuk mereduksi perilaku agresif siswa dengan melakukan Self-Control Training teknik ABC atau solutionfocused brief counseling.
\end{abstract}

Kata Kunci: self-control training, solution-focused brief counseling, antecedent-behavioralconsequence model, perilaku agresif

\section{INTRODUCTION}

Aggressive behaviour phenomena have become a great concern for society. Aggressive behaviours have not only been committed by people with the low level of life, but also by those from the middle or middle to high society, and even, by the government employees. Students of 
the high school levels are not free from the inclination of doing aggressive behaviours.

Aggressive behaviour is an act that impresses an action that hurts a peer by way of a certain method (Hamama \& Ronen-Shenhav, 2012; Murray et al., 2016; Restu et al., 2013; Tucker et al., 2014). Aggressive behaviors can be reflected in psychological, emotional, or physical harm to the targeted person (Aquino \& Thau, 2009; A. L. Duckworth \& Carlson, 2013) in the form of a verbal or physical harassment. An indepth study needs to be carried out on aggressive behaviours in the characteristics, causes, as well as prevention conceptually (based on theories and research) and systemically (according to scientific procedures) (Cohen \& Lieberman, 2010; Daly et al., 2015; Denson et al., 2011).

Aggressive behaviours can be caused by various factors; however, primarily by the inability to do self-control (DeWall et al., 2011; Salmi, 2015). Therefore, in order to reduce aggressive behaviours, one needs to increase self-control (A. Duckworth \& Gross, 2014; A. L. Duckworth \& Steinberg, 2015; Griffin et al., 2012), and not be intrigued to do something for temporal satisfaction (Ang et al., 2016; Roy F. Baumeister et al., 2007; A. L. Duckworth et al., 2019). Besides, Denson et al. (2012) emphasize that strengthening self-control will be able to decrease aggressive behaviours.

Several studies have been conducted to find effective ways to overcome aggressive behaviours. A study by Fritzhand et al. (2017) recommends overcoming aggressive behaviours by way of sports. Another study conducted by Hardoni et al. (2019), proposed using a replacement object. These techniques have been oriented on controlling behaviours; they are not focused on the primary causes of the breaking out of aggressive behaviours. Since the main factor of the aggressive behaviour development is the low level of self-control.

A person with a strong measure of selfcontrol will tend to be able to do away with the inclination of aggressive behaviours (Hastuti, 2018). On the contrary, weak self-control will tend to contribute to the violence, such as in the domestic violence (Finkenauer et al., 2015). Previous research has shown that self-control has a positive contribution in lowering aggressive behaviours (Denson et al., 2011; Miranda \& Presentacion, 2000; Yusainy \& Lawrence, 2020; Zahrani \& Ambarini, 2019).

Factors that have been known to influence self-control are personality, environment, and intervention. Personal factors include age, temperament, gender, and cognitive processes. Environmental factors include parents, teachers, peers, relatives, learning environment, household environment, playmates, language, media, and cultures. Meanwhile, intervention factors include training in self-control (Fox \& Calkins, 2003; Peterson \& Seligman, 2004). Among the three factors, deliberate intervention in the form of self-control training has the most dominant influence since, theoretically, such training intervention is deliberately designed to increase self-control by involving both personal and environmental factors. It is therefore believed that self-control training has become the key for increasing self-control to curb aggressive behaviours (Manuel Sofia \& Cruz, 2015). Selfcontrol training goes even so far as having a significant impact on attitudes, mental health, and academic achievement (Allom et al., 2016; A. L. Duckworth \& Carlson, 2013; Fujita, 2011; Job et al., 2015; Ridder et al., 2012).

Other previous studies on self-control training report the use of cognitive-behavioral training to increase self-control levels and reduce aggressive behaviours (Etscheidt, 1991), the use of self-regulation (Denissen et al., 2018), and the use of irregular hands to carry out daily activities (Denson et al., 2011). However, not many studies have been found that use the ABC method in selfcontrol training in inhibiting aggressive behaviours. It is this gap that the present study intends to fill up.

Although not many studies have been found to test the effectiveness of the $A B C$ training method to reduce aggressive behaviours, it is believed to be effective. It intervenes the causes that trigger aggressive behaviours comprehensively using the antecedent manipulating technique (A), intervenes adaptive behaviours through behaviour manipulation (B), intervenes the consequences of the aggressive behaviours by consequence manipulation (C) (Calhoun, 1990). This is how the $\mathrm{ABC}$ manipulation technique is deemed to be more effective as it comprehensively treats all the factors for the emergence of aggressive behaviour, namely its causes, its symptoms, and its consequences.

Solution-focused Brief Counseling (SFBC) is an approach to counseling based on the strength generated by the counselee that is focused more on the development of problemsolution rather than on the tracing of the factors of the problem (C. N. Jones et al., 2009). This counselling model is based on the assumption 
that every healthy individual possesses the competencies and is able to construct a solution that can change their life (Corey, 2013). Jones et al. (2009) state that the effectiveness of the SFBC model to help young adults in solving their problems in the educational contexts lacks empirical evidence. Therefore, Jones et al. (2009) recommend the need to test the effectiveness of the SFBC model in helping students to solve their problems.

Inspired by this recommendation, research was conducted to test the effectiveness of the SFBC model to prevent students' aggressive behaviour. Based on the study by Ashidiq (2019), physical aggressive behaviours done by students include punching, banging tables, pushing, hitting the door, throwing off the TV remote control, breaking objects, and pinching one's ears. Verbal aggressive behaviours include mocking and insulting.

Some studies have been carried out to test the effectiveness of the SFBC model. Fitriyah (2017), conducting a study that involves highschool students in West Java, Indonesia, reports that the SFBC model is effective in reducing aggressive behaviours. Putri et al (2019), did a study that involves grade 12 students of Muhammadiyah High School in Prambanan, Middle Java, Indonesia and found that the SFBC model was effective in reducing students' socially aggressive behaviours. Meanwhile, Wiretna \& Wahyu (2020), in their study involving grade 10 students of the SMK Muhammadiyah 1 Yogyakarta, Indonesia, found a decrease in students' online aggressions after the treatment of the SFBC model.

Evidence presented by the foregoing studies cannot be deemed adequate to show that the SFBC model is effective in reducing aggressive behaviours in all contexts. Further studies need to be conducted-to draw more valid and reliable conclusions.

The present study was intended to describe the differences in the effectiveness of solutionfocused brief counseling (SFBC) and self-control training using the manipulative techniques of Antecedent-Behaviour-Consequence (ABC) to reduce the inclination of high school students to do aggressive behaviours.

\section{METHODS}

The study was experimental research using the pretest-posttest control group design. The research design is presented in Table 1 .
Experiment 1 group was given the SFBC treatment and Experiment 2 group was given the $\mathrm{ABC}$ treatment. The Control group did not receive any special treatment but the conventional guidance and counseling services, which were given daily by the guidance and counselling teachers.

\section{Table 1. Research Design}

\begin{tabular}{cccc}
\hline Group & Pre-test & Treatment & Post Test \\
\hline Experiment 1 & O1 & $\mathrm{X} 1$ & $\mathrm{O} 4$ \\
Experiment 2 & $\mathrm{O} 2$ & $\mathrm{X} 2$ & $\mathrm{O} 5$ \\
Control & $\mathrm{O} 3$ & - & O6 \\
\hline
\end{tabular}

Notes:

$\mathrm{O} 1, \mathrm{O} 2, \mathrm{O} 3=$ Pre-test score

O4, O5, O6 = Post-test score

$\mathrm{X} 1=$ Solution-focused brief counseling

$\mathrm{X} 2=$ Self-control training by the $\mathrm{ABC}$ manipulative techniques

= No research treatment; conventional guidance and counseling daily given by the guidance and counseling teachers including to Experiment 1 and Experiment 2 groups

Table 2. Characteristics of Research Samples

\begin{tabular}{lcc}
\hline \multicolumn{1}{c}{ Characteristics } & Total & Percentage \\
\hline Experiment Group 1 & & \\
Male & 11 & 55 \\
Female & 9 & 45 \\
Total & 20 & 100 \\
Experiment Group 2 & & \\
Male & 13 & 65 \\
Female & 7 & 35 \\
Total & 20 & 100 \\
Control Group & & \\
Male & 12 & 60 \\
Female & 8 & 40 \\
Total & 20 & 100 \\
\hline
\end{tabular}

The research population consisted of 563 students of grade 11 from SMA N 1, SMA N 2, and SMAS Lab Undiksha Singaraja (SMA N is a Public School and SMA S is a Private School). They are all located in Singaraja, Bali, Indonesia. Sixty students were chosen by a simple random sampling technique. The sample was divided into three groups, namely Experiment Group 1, Experiment Group 2, and Control Group which consist of 20 students each. Characteristics of the research samples are presented in Table 2.

Research data were collected directly using a non-test technique. The non-test research instrument was the Aggression Questionnaire (AQ) consisting of 25 statement items measuring four dimensions of aggressive behaviours. The specification for the complete items of the AQ is presented in Table 3. Content validation for the AQ was conducted by three experts; one from the 
Research and Evaluation field and two from the Guidance and Counseling field. Results of the instrument validation are presented in Table 4. The instrument reliability measure was appraised from the Alpha-Cronbach formula showing a reliability co-efficient of 0.901 with the very high reliability.

Research data were analyzed by descriptive and inferential statistics. The descriptive statistics included means, standard deviations, maximum scores, and minimum scores. The inferential statistics were the one-way Anova and the $t$-test following the pre-requisite tests for the normal distribution and variance homogeneity. The Anova statistics were used to test the differences in means of the pre-test and post-test scores for the experiment and control groups. All statistical analyses were processed on the IBM SPSS Statistics 22.0 for Windows.

\section{FINDINGS AND DISCUSSION}

\section{Findings}

Data analyses are conducted to know the differences in the effectiveness among solutionfocused brief counseling (SFBC), Self-Control Training of the $\mathrm{ABC}$ technique, and conventional guidance and counseling services in reducing students' aggressive behaviours. Analysis results are presented in four parts: (i) descriptive analyses of the pre-test and post-test data among the experiment and control groups, (ii) statistical prerequisites for the pre-test and post-test data, (iii) the Anova test, and (iv) the $t$-statistic.

Descriptive Analyses
Results of the descriptive statistical analyses of the experiment and control groups are presented in Table 5.

\section{Statistical Prerequisites}

\section{Normality of Data Distribution}

Normality of the data distribution of the experiment and control groups is praised using the Kolmogorov-Smirnov test. Results are presented in Table 6. Test results for the normality of the data distribution show that data for all the research groups have a normal distribution.

\section{Homogeneity of Variance}

Variance homogeneity of the pre-test and post-test data is assessed by using the Levene test. Results can be seen in Table 7. Based on the results of the homogeneity test, the Levene test shows a significance coefficient of 0.895 for the pre-test data and 0.683 for the post-test data, indicating variance homogeneity for the data sets.

\section{Anova}

Results of the Anova Test on the Pre-Test Data

Table 8 presents the results of the Anova statistical test for the pre-test data of the three groups: SFBC, ABC, and conventional counseling. Based on the Anova test results, an $F$ score of 0.120 is obtained with a significance level of 0.887 (Sig. > 0.05). It can be interpreted that there is no significant difference in the scores of aggressive behaviours among the three research groups. It can be stated that, at the beginning of the research treatments, the characteristics of the students' aggressive behaviours in the three groups are the same or equal.

Table 3. Specification of The Aggression Questionnaire

\begin{tabular}{cllc}
\hline No. & Dimension & Indicator & $\begin{array}{c}\text { Item } \\
\text { Number }\end{array}$ \\
\hline 1. & Attack on bodies & Hitting, kicking, slapping, using tools to attack & 10 \\
2. & Attack on objects & Throwing and breaking objects & 5 \\
3. & Attack verbally or symbolically & Swearing, mocking, threatening & 5 \\
4. & Harassment of others' belonging & Coercing, destroying others' belonging & 5 \\
& or others' space & Total: & 25 \\
\hline
\end{tabular}

Table 4. Result of Content Validity Test

\begin{tabular}{cccccccccc}
\hline $\begin{array}{c}\text { No. } \\
\text { Item }\end{array}$ & V Index & $\begin{array}{c}\text { No. } \\
\text { Item }\end{array}$ & $\begin{array}{c}\text { V } \\
\text { Index }\end{array}$ & $\begin{array}{c}\text { No. } \\
\text { Item }\end{array}$ & $\begin{array}{c}\text { V } \\
\text { Index }\end{array}$ & $\begin{array}{c}\text { No. } \\
\text { Item }\end{array}$ & $\begin{array}{c}\text { V } \\
\text { Index }\end{array}$ & $\begin{array}{c}\text { No. } \\
\text { Item }\end{array}$ & $\begin{array}{c}\text { V } \\
\text { Index }\end{array}$ \\
\hline 1. & 0.83 & 6. & 0.80 & 11. & 0.80 & 16. & 0.90 & 21. & 0.87 \\
2. & 0.90 & 7. & 0.80 & 12. & 0.83 & 17. & 0.90 & 22. & 0.83 \\
3. & 0.87 & 8. & 0.90 & 13. & 0.80 & 18. & 0.90 & 23. & 0.80 \\
4. & 0.83 & 9. & 0.83 & 14. & 0.80 & 19. & 0.90 & 24. & 0.87 \\
5. & 0.80 & 10. & 0.80 & 15. & 0.90 & 20. & 0.90 & 25. & 0.90 \\
\hline
\end{tabular}


Results of the Anova Test on the Post-Test Data

Results of the Anova test on the post-test data of the three research groups can be seen in Table 9. Results of the Anova statistical computation in Table 9 show an F score of 348.300 with a significance level of 0.000 (Sig. < 0.05).

It can be interpreted that there is a significant difference in the aggression scores among the SFBC, ABC, and conventional counseling groups in the post-test scores. It can further be stated that, after receiving the research treatments, the three research groups show significant differences in their scores of aggressive behaviours. Differences in the students' aggression scores before and after treatments can be seen in Figure 1.

From Figure 1, it can be seen that there is a lowering trend in the mean scores of the research groups before and after receiving the treatments. The highest decrease occurs in experiment group 2, the one receiving the self-control training of the $\mathrm{ABC}$ manipulative techniques. It isfollowed by experiment group 1 that is given the solution-focused brief counseling (SFBC). The lowest rate in the decrease occurs in the control group who receives conventional counseling services.

Based on these statistical results, it can be stated that both SFBC and ABC counseling techniques are effective in reducing students' aggressive behaviours. To find out the levels of effectiveness of SFBC and ABC counseling techniques in reducing students' aggressive behaviours, the scores are subjected to the $t$ and effect size tests.

Results of the $\mathrm{t}$ and Effect Size Tests

The $t$ and effect size tests are performed three times: (1) for the SFBC data, (2) for the $\mathrm{ABC}$ data, and (3) for comparing the effectiveness of the SFBC technique and the $\mathrm{ABC}$ technique. The $t$-test is done on the SPSS 22.0 program and the effect size test is done by using the Cohen formula (1988) as follows.

$D=\frac{M_{1}-M_{2}}{S_{p}}$

$S_{p}=\sqrt{\frac{\left(N_{1}-1\right) \cdot S_{1}^{2}+\left(N_{2}-1\right) \cdot S_{2}^{2}}{N_{1}+N_{2}-2}}$

where $\mathrm{D}$ is effect size, $\mathrm{M}$ is mean, $\mathrm{Sp}$ is pooled standard deviation, $\mathrm{N}$ is the number of the group members, and $\mathrm{S}$ is group standard deviation. Results of the tests can be seen in Table 10 .

From Table 10, it can be stated that the SFBC technique is effective in reducing students' aggressive behaviours (Sig.=0.000), so is the $\mathrm{ABC}$ technique (Sig. 0. $=000$ ). Meanwhile, the $\mathrm{ABC}$ technique is more effective than the SFBC technique $($ Sig. $=0.000)$.

Table 5. Results of Descriptive Analysis

\begin{tabular}{lccccc}
\hline \multicolumn{1}{c}{ Group } & N & Minimum & Maximum & Mean & Std. Deviation \\
\hline Pre-test Data & & & & & \\
Experiment Group 1 (O1) & 20 & 77.00 & 98.00 & 87.5500 & 4.53611 \\
Experiment Group 2 (O2) & 20 & 76.00 & 97.00 & 86.8500 & 4.65974 \\
Control Group (O3) & 20 & 78.00 & 97.00 & 87.2000 & 4.33590 \\
Post test Data & & & & & \\
Experiment Group 1 (O4) & 20 & 50.00 & 70.00 & 58.9000 & 4.47096 \\
Experiment Group 2 (O5) & 20 & 41.00 & 62.00 & 49.5000 & 5.07315 \\
Control Group (O6) & 20 & 74.00 & 95.00 & 84.5500 & 4.68452 \\
Valid N (listwise) & 20 & & & &
\end{tabular}

Notes: Data of the aggressive behaviours for the experiment and control groups are elicited using the same instrument: the Aggression Questionnaire (AQ)

Table 6. Results of Normality of Data Distribution

\begin{tabular}{|c|c|c|c|c|c|c|c|}
\hline & & $\begin{array}{c}\text { Pre-test } \\
\text { EG1 } \\
\end{array}$ & $\begin{array}{c}\text { Pre-test } \\
\text { EG } 2 \\
\end{array}$ & $\begin{array}{c}\text { Pre-test } \\
\text { CG }\end{array}$ & $\begin{array}{c}\text { Posttest } \\
\text { EG1 }\end{array}$ & $\begin{array}{c}\text { Post test } \\
\text { EG } 2 \\
\end{array}$ & $\begin{array}{c}\text { Posttest } \\
\text { CG }\end{array}$ \\
\hline \multicolumn{2}{|l|}{$\mathbf{N}$} & 20 & 20 & 20 & 20 & 20 & 20 \\
\hline \multirow[t]{2}{*}{ Normal Parameters ${ }^{\mathrm{a}, \mathrm{b}}$} & Mean & 87.5500 & 86.8500 & 87.2000 & 58.9000 & 49.5000 & 84.5500 \\
\hline & Std. Deviation & 4.53611 & 4.65974 & 4.33590 & 4.47096 & 5.07315 & 4.68452 \\
\hline \multirow[t]{3}{*}{ Most Extreme Differences } & Absolute & .175 & .120 & .189 & .153 & .139 & .150 \\
\hline & Positive & .175 & .100 & .189 & .153 & .139 & .150 \\
\hline & Negative & -.137 & -.120 & -.141 & -.108 & -.095 & -.093 \\
\hline Test Statistic & & .175 & .120 & .189 & .153 & .139 & .150 \\
\hline Asymp. Sig. (2-tailed) & & $.112^{\mathrm{c}}$ & $.200^{\mathrm{c}, \mathrm{d}}$ & $.059^{\mathrm{c}}$ & $.200^{\mathrm{c}, \mathrm{d}}$ & $.200^{\mathrm{c}, \mathrm{d}}$ & $.200^{\mathrm{c}, \mathrm{d}}$ \\
\hline Conclusion & & Normal & Normal & Normal & Normal & Normal & Normal \\
\hline
\end{tabular}

Notes: EG (Experiment group; CG (Control group) 
Table 7. Results of Homogeneity Test

\begin{tabular}{lcccc}
\hline & Levene Statistic & df1 & df2 & Sig. \\
\hline Pre-test data & .111 & 2 & 57 & .895 \\
Post test data & .384 & 2 & 57 & .683 \\
\hline
\end{tabular}

Table 8. Results of The Anova Test for The Pre-Test Data

\begin{tabular}{llccccc}
\hline & & Sum of Squares & $\boldsymbol{d} \boldsymbol{f}$ & Mean Square & $\boldsymbol{F}$ & Sig. \\
\hline Pre-test Data & Between Groups & 4.900 & 2 & 2.450 & .120 & .887 \\
& Within Groups & 1160.700 & 57 & 20.363 & & \\
& Total & 1165.600 & 59 & & & \\
\hline
\end{tabular}

Table 9. Results of The Anova Test for The Post-Test Data

\begin{tabular}{llrrrrr}
\hline & \multicolumn{1}{c}{ Sum of Squares } & $\boldsymbol{d} \boldsymbol{f}$ & Mean Square & $\boldsymbol{F}$ & \multicolumn{1}{c}{ Sig. } \\
\hline Post test Data & Between Groups & 15713.233 & 2 & 7856.617 & 348.300 & .000 \\
& Within Groups & 1285.750 & 57 & 22.557 & & \\
& Total & 16998.983 & 59 & & & \\
\hline
\end{tabular}

Table 10. Results of The $t$ and Effect Size Tests

\begin{tabular}{|c|c|c|c|c|c|}
\hline No. & Effectiveness & $t$ & Sig. & Pooled SD & Effect Size \\
\hline 1. & SFBC* & -17.714 & 0.000 & 4.579 & 5.602 \\
\hline 2. & SCT-ABC** & -22.700 & 0.000 & 4.883 & 7.178 \\
\hline 3. & Difference between SFBC and $\mathrm{ABC}$ & 6.217 & 0.000 & & \\
\hline
\end{tabular}

*SFBC: Solution-focused based counseling

**ABC: Self-control training of the ABC manipulative technique

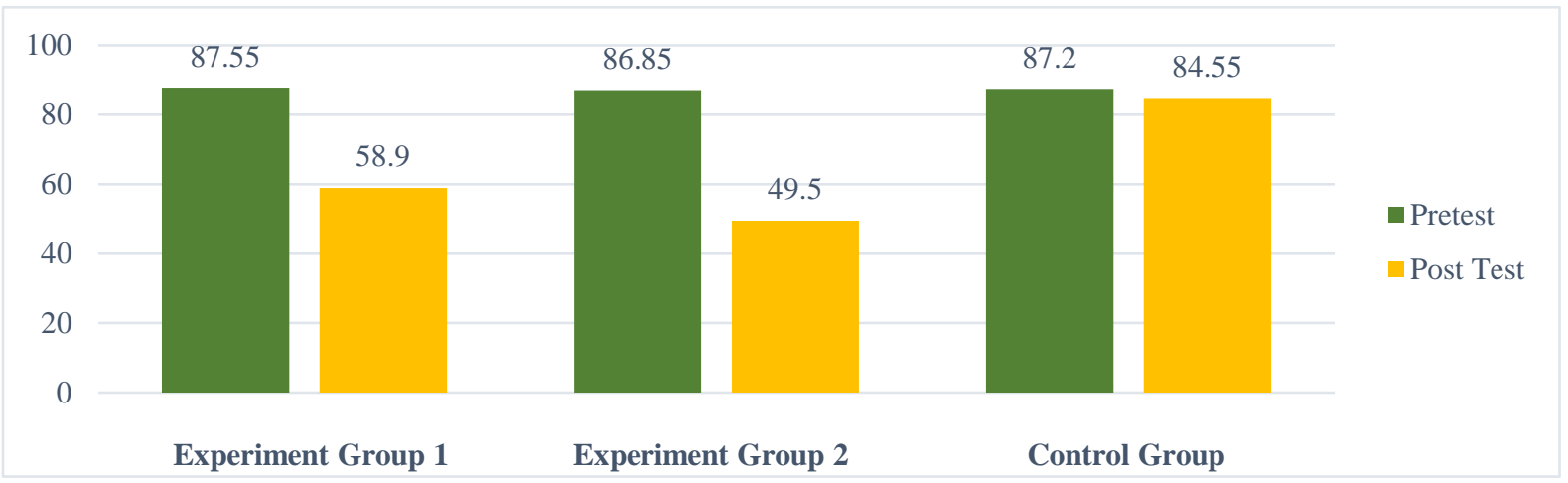

Figure 1. Comparison of the pre-test and post-test scores among the research groups

\section{Discussion}

Results of the present study show that both the SFBC and the ABC are effective in reducing senior high school students' aggressive behaviours. The $\mathrm{ABC}$ technique, however, is more effective than the SFBC. There is a significant difference in the level of aggressive behaviours between the students who receive the SFBC and $\mathrm{ABC}$ treatments and those who receive conventional services in guidance and counseling. Students in the ABC treatment group show the lowest level of aggressive behaviours compared to those from either the SFBC counseling or conventional counseling.

In other words, the self-control training using the $\mathrm{ABC}$ manipulative technique is the most effective to be used for lowering the level of the high school students' aggressive behaviours. Aggressive behaviours could lead to hurting other people (Anderson \& Bushman, 2001;
Rahman, 2014) in the forms of verbal and physical attacks that impinge wounds on people (Denson et al., 2010; A. L. Duckworth et al., 2016; Lawrence, 2006). These behaviours are very closely related to intuition. In the theory of intuition, all persons have the intuition of life and intuition of death (Rahman, 2014). According to this theory, aggressive behaviours derive from the intuition of death. Since aggressive behaviours are intuitive, all people have the potentials to behave aggressively; and this inclination will become actual when there are factors that move these behaviours to materialize. The social learning theory views aggressive behaviours as a ramification for persons who see and imitate a model who shows aggressive behaviors (Berkman, 2016). Finally, the cognitive theory looks at how a person manages and interprets information about a stimulus that triggers aggression in the mind and causes aggressive behaviours (Heatherton \& Wagner, 2011). 
Meanwhile, the behavioristic theory sees aggressive behaviours as learning acquired from the environment (Hofmann \& Kotabe, 2012). When a person does an aggressive behaviour and the behaviour is reinforced, it will re-occur in the future. On the other hand, when the behaviour is not reinforced, or even impacts pain (punishment), it will tend to be avoided in the future (Bensley \& Van Eenwyk, 2001; James \& LeBreton, 2010; A. Jones et al., 2016).

By referring to the psychoanalytic, social learning, cognitive, and behavioristic theories concerning aggressive behaviours, Gading (2014) describes the self-control training model using the $\mathrm{ABC}$ manipulation. The occurrence of aggressive behaviours can be explained in a process as shown in Figure 2.

As it is shown in Figure 2, three factors influence aggressive behaviours, which are individual factors, environmental factors, and deliberate intervention. Deliberate intervention, in the form of self-control training, will enhance self-control, the ability to think over and make decision which will determine whether the emerging behaviour is aggressive or not. When a person has good self-control, aggressive behaviours can be avoided. The ensuing consequence, be it reinforcement or punishment, will influence the occurrence of aggressive behaviours in the future.

The findings of the present study agreed to those of Bensley \& Eenwyk (2001) in which it showed how aggressive behaviours can be influenced by video games that contain violence. Children who frequently watch video games containing violence are apt to have a high inclination to do aggressive behaviours. Denson et al. (2011) state that self-control training is able to minimize aggressivity in responding to provocation. Similarly, Kuhnle et al. (2011) emphasize that self-control has a positive correlation with one's motivation to do good deeds. Self-control training plays an important part for a person in responding to various situations. Denson et al. (2012) state that selfcontrol is important to decrease a person's aggressive behaviours. Gading (2014) also states that self-control training can help in preventing and overcoming academic procrastinations. Students who receive self-control training tend to be more able to prevent and overcome procrastinations than students who do not.

The present study and other previous studies have strengthened the successfulness and effectiveness of the $\mathrm{ABC}$ self-control training in reducing the inclination of the high school students to do aggressive behaviours. It is, however, true that such claim needs to be studied further and more in-depths. Self-control is a person's ability to manage and direct behaviours towards the ideal, moral, and social norms to be in line with the society's expectations. Denson et al. (2012) stresses that strengthening self-control will reduce aggressive behaviours. Good selfcontrol will be able to annihilate aggressive behaviours (Hastuti, 2018). On the contrary, weak self-control plays an important factor in violence, such as in the case of domestic violence (Finkenauer et al., 2015). It is therefore true that self-control training is a key medium to curb aggressivities (Manuel Sofia \& Cruz, 2015). Selfcontrol training even has positive impacts on one's improvement in behaviour, health, mentality, and academic achievement (Allom et al., 2016; A. L. Duckworth \& Carlson, 2013; Fujita, 2011; Job et al., 2015; Ridder et al., 2012). The ABC model of self-control training has a good system or procedure and is considered simple so that it can be applied easily for the young adults, especially high-school students.

The detailed procedure of the ABC selfcontrol training model consists of several steps. The first step is describing the problem, which entails writing the problem description simply, objectively, and comprehensively, using the selfmonitor for complete scanning. In this activity, the participants are trained to be sensitive in looking at the problem clearly. The second step includes identifying internal and external antecedent, that is where the participants identify the internal and external consequences of the behaviour. The participants are trained to recognize that every behaviour has its cause and consequences. The third procedure is manipulating the antecedent, which participants describe the circumstances to avoid stimuli, make or delete procrastination, decrease, or increase associations, compensate attention to other behaviours, or make restatement or arrangement. This activity trains the participants to do selfcontrol through manipulation so that they have the habit of doing controlled actions. The fourth step is about responding manipulation (behavioral) and the activity consists of intervening, shuffling, lengthening, or shortening the behaviour chain; replacing actions with irrelevant activities and shaping the behaviour. These activities give the participants experience 
and feelings that arise from their actions. The last step is manipulating the consequence, where the participants make use of the feedbacks for improvement through self-monitoring, giving reward or punishment to self, be it is symbolic or real, and selecting awards on the Premark principle. In this stage, participants are trained to recognize that good behaviours deserve rewards and bad ones deserve punishment (Calhoun, 1990). Through these steps, participants learn to direct thoughts, feelings, and actions so that their behaviours will always be in line with the social norms, including social expectations.

The ABC self-control training model is found to be effective in reducing a person's aggressive behaviours. There is still a question, however, why the technique, having the better claim theoretically and operationally, has not been able to maximally reduce the aggressive behaviours of all children. Some assuming factors includes the length of time of the training, which has not accommodated the different time needed by each child. Children need to have different lengths of time to change their initial behaviour patterns into the expected behaviour. It is therefore important to provide different children with different lengths of the training time.

In order to increase the effectiveness of the $\mathrm{ABC}$ self-control training model, five efforts can be done concerning the procedure of the training conduct. First, in the phase of describing the problem, the best way is by making sure that the problem being described is objective and easy to understand. Second, during the activities of the examination of the internal and external antecedent and the internal and external consequences, the students should make sure that they are aware of and understand the consequences of their actions. Third, in the stage of manipulating the antecedents, the students must be watchful towards the manipulation that is done in their full self-confidence. Fourth, in the stage of the response manipulation (behavioral), the students must watch for the feelings that arise from the actions. Fifth, in the stage of manipulating consequences, the students must be able to feel the results of what they have done.

The indings of the present study imply that the application of self-control training models must be conducted accurately to bring about results in decreasing aggressive behaviours. The $\mathrm{ABC}$ self-control training model is one of the most effective models that can be implemented. With the ABC model, one can prevent and curb aggressive actions that impacted other people. To have good self-control, children must be introduced to this mental development as early as possible (Daly et al., 2015) since each child has a different pattern of self-control development. When children have good self-control, they will be able to minimize actions that will impact impairment onto themselves and other people (R. F. Baumeister \& Vohs, 2016; Hofmann et al., 2014).

Another research implication points to the need of providing different time allocations in the self-control training for different ages of children. This needs to be taken into consideration as different children have different abilities and competencies in internalizing and practicing the expected behaviours. The theory Single-episode General Aggression Model (Anderson \& Bushman, 2001) stipulates that situational input variables influence aggressive behaviours through the individuals' internal conditions It was represented by the cognitive and affective generator variables and the triggering factor. Self-control, the ability to consider and make decision that can be developed through selfcontrol training, is a determining factor for an individual to act (R. F. Baumeister \& Vohs, 2016; Carter et al., 2015). If people have the ability to consider and make decision, they will have smart behaviours (decent and wise). On the contrary, if people can not consider and make decision, they will have impulsive or aggressive behaviours (Magen \& Gross, 2010; Piquero et al., 2016)(Magen \& Gross, 2010; Piquero et al., 2016). Their behaviours (whether aggressive or not) that occur in a social interaction will become a new situational factor which will interact with personal factors to induct a particular behaviour soon (Allom et al., 2016; Miles et al., 2016). It can therefore be stated that an individual's ability to consider and make decision will influence the circle of the subsequent behaviours, i.e. the cycle of smart (thoughtful) actions or that of aggressive (impulsive) behaviours. 


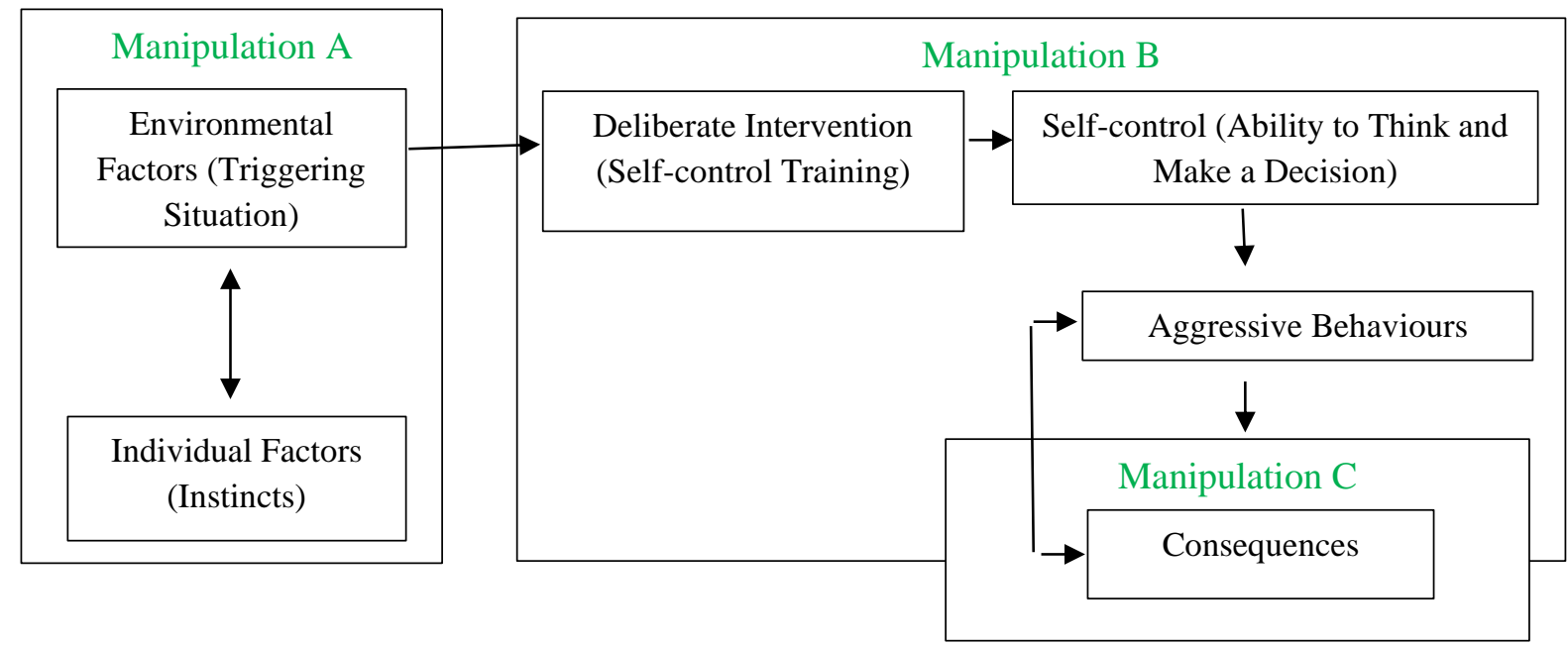

Figure 2. Aggressive behaviour model in the self-control training of the ABC manipulative technique

\section{CONCLUSION}

The self-control training with the antecedent-behaviour-consequence (ABC) model is effective in reducing high-school students' aggressive behaviours. The students who have received the $\mathrm{ABC}$ training have shown a lower level of aggressive behaviours than those who have been given the conventional technique of counseling. It is therefore properly expected by the teachers (especially guidance-counselor teachers) to attempt self-control training, especially using the $\mathrm{ABC}$ manipulative technique. The findings of the present study have shown the important use of the proper techniques in self-control training to reduce students' aggressive behaviours. It has also be shown that the $\mathrm{ABC}$ manipulative technique is one of the most effective models for effective self-control training.

\section{ACKNOWLEDGEMENTS}

We would like to acknowledge our thankfulness to (1) Ganesha Educational University who has given us the research fund so that we can complete this study well; (2) Principal of the Senior High School in Singaraja City for having permitted us to involve their students to become participants in the present study; and (3) students of Singaraja City Senior High School for having participated as the subjects of the study.

\section{REFERENCES}

Allom, V., Mullan, B., \& Hagger, M. (2016). Does inhibitory control training improve health behaviour? A meta-analysis. Health Psychology Review, 10(2), 168-186. https://doi.org/10.1080/17437199.2015.10

\section{8}

Anderson, C. A., \& Bushman, B. J. (2001). Effects of violent video games on aggressive behavior, aggressive cognition, aggressive affect, physiological arousal, and prosocial behavior: A meta-analytic review of the scientific literature. Psychological Science, 12(5), 353-359. https://doi.org/10.1111/1467-9280.00366

Ang, R. P., Huan, V. S., Li, X., \& Chan, W. T. (2016). Functions of aggression and delinquency: The moderating role of parent criminality and friends' gang membership. Journal of Interpersonal Violence, 33(22), 3531-3550. https://doi.org/10.1177/088626051663606 6

Aquino, K., \& Thau, S. (2009). Workplace victimization: Aggression from the target's perspective. Annual Review of Psychology, 60(1), 717-741. https://doi.org/10.1146/annurev.psych.60.1 10707.163703

Ashidiq, K. (2019). Perilaku agresif siswa SMP. Yinyang: Jurnal Studi Islam Gender Dan Anak, 14(1), 135-153. https://doi.org/10.24090/yinyang.v14i1.28 45

Baumeister, R. F., \& Vohs, K. D. (2016). Strength model of self-regulation as limited resource: Assessment, controversies, update. In Advances in Experimental Social Psychology (Vol. 54, pp. 67-127). https://doi.org/10.1016/bs.aesp.2016.04.00 1

Baumeister, Roy F., Vohs, K. D., \& Tice, D. M. 
(2007). The strength model of self-control. Current Directions in Psychological Science, 16(6), 351-355.

Bensley, L., \& Van Eenwyk, J. (2001). Video games and real-life aggression: Review of the literature. Journal of Adolescent Health, 29(4), 244-257. https://doi.org/10.1016/S1054139X(01)00239-7

Berkman, E. (2016). Self-regulation training. In K. D. Vohs \& R. F. Baumeister (Eds.), Handbook of Self-Regulation: Research, Theory, and Applications (3rd ed., pp. 440457).

Calhoun, J. F. (1990). Psychology of adjustment and human relationships (3rd ed.). McGraw-Hill.

Carter, E. C., Kofler, L. M., Forster, D. E., \& McCullough, M. E. (2015). A series of meta-analytic tests of the depletion effect: Self-control does not seem to rely on a limited resource. Journal of Experimental Psychology: General, 144(4), 796-815. https://doi.org/10.1037/xge0000083

Cohen, J. R., \& Lieberman, M. D. (2010). The common neural basis of exerting selfcontrol in multiple domains. In R. Hassin, K. Ochsner, \& Y. Trope (Eds.), Self Control in Society, Mind, and Brain (pp. 141-161). Oxford University Press. https://doi.org/10.1093/acprof:oso/978019 5391381.003.0008

Corey, G. (2013). Theory and practice of counseling and psychotherapy. In Brooks/Cole (9th ed.). Brooks/Cole Cengage Learning.

Daly, M., Delaney, L., Egan, M., \& Baumeister, R. F. (2015). Childhood self-control and unemployment throughout the life span. Psychological Science, 26(6), 709-723. https://doi.org/10.1177/095679761556900 1

Denissen, J. J. A., Bleidorn, W., Hennecke, M., Luhmann, M., Orth, U., Specht, J., \& Zimmermann, J. (2018). Uncovering the power of personality to shape income. Psychological Science, 29(1), 3-13. https://doi.org/10.1177/095679761772443 5

Denson, T. F., Capper, M. M., Oaten, M., Friese, M., \& Schofield, T. P. (2011). Self-control training decreases aggression in response to provocation in aggressive individuals.
Journal of Research in Personality, 45(2), 252-256.

https://doi.org/10.1016/j.jrp.2011.02.001

Denson, T. F., DeWall, C. N., \& Finkel, E. J. (2012). Self-control and aggression. Current Directions in Psychological Science, 21(1), 20-25. https://doi.org/10.1177/096372141142945 1

Denson, T. F., von Hippel, W., Kemp, R. I., \& Teo, L. S. (2010). Glucose consumption decreases impulsive aggression in response to provocation in aggressive individuals. Journal of Experimental Social Psychology, 46(6), 1023-1028. https://doi.org/10.1016/j.jesp.2010.05.023

DeWall, C. N., Anderson, C. A., \& Bushman, B. J. (2011). The general aggression model: Theoretical extensions to violence. Psychology of Violence, 1(3), 245-258. https://doi.org/10.1037/a0023842

Duckworth, A., \& Gross, J. J. (2014). Selfcontrol and grit. Current Directions in Psychological Science, 23(5), 319-325. https://doi.org/10.1177/096372141454146 2

Duckworth, A. L., \& Carlson, S. M. (2013). Selfregulation and school success. In B. W. Sokol, F. M. E. Grouzet, \& U. Muller (Eds.), Self-Regulation and Autonomy: Social and Developmental Dimensions of Human Conduct (pp. 208-230). Cambridge University Press. https://doi.org/10.1017/CBO97811391521 98.015

Duckworth, A. L., Gendler, T. S., \& Gross, J. J. (2016). Situational strategies for selfcontrol. Perspectives on Psychological Science, 11(1), 35-55. https://doi.org/10.1177/174569161562324 7

Duckworth, A. L., \& Steinberg, L. (2015). Unpacking self-control. Child Development Perspectives, 9(1), 32-37. https://doi.org/10.1111/cdep.12107

Duckworth, A. L., Taxer, J. L., Eskreis-Winkler, L., Galla, B. M., \& Gross, J. J. (2019). Selfcontrol and academic achievement. Annual Review of Psychology, 70(1), 373-399. https://doi.org/10.1146/annurev-psych010418-103230

Etscheidt, S. (1991). Reducing aggressive behavior and improving self-control: A 
cognitive-behavioral training program for behaviorally disordered adolescents. Behavioral Disorders, 16(2), 107-115. https://doi.org/https://doi.org/10.1177/0198 74299101600204

Finkenauer, C., Buyukcan-Tetik, A., Baumeister, R. F., Schoemaker, K., Bartels, M., \& Vohs, K. D. (2015). Out of control. Current Directions in Psychological Science, 24(4), 261-266. https://doi.org/10.1177/096372141557073 0

Fitriyah, F. K. (2017). Reducing aggressive behavior using solution-focused brief counseling (SFBC). JBKI: Jurnal Bimbingan Konseling Indonesia, 2(2), 3439.

https://doi.org/http://dx.doi.org/10.26737/j bki.v2i2.254

Fox, N. A., \& Calkins, S. D. (2003). The development of self-control of emotion: Intrinsic and extrinsic influences. Motivation and Emotion, 27(1), 7-26. https://doi.org/https://doi.org/10.1023/A:10 23622324898

Fritzhand, A., Kitkanj, Z., Anastasovski, I., \& Velichkovska, L. A. (2017). The role of sports in overcoming aggression in children and adolescents. Research in Phisical Education, 6(2), 109-111.

Fujita, K. (2011). On conceptualizing self-control as more than the effortful inhibition of impulses. Personality and Social Psychology Review, 15(4), 352-366. https://doi.org/10.1177/108886831141116 5

Gading, I. K. (2014). Pengaruh pelatihan kendali diri dan jenis kelamin terhadap perilaku prokrastinasi akademik siswa SMP. Universitas Negeri Malang.

Griffin, K. W., Scheier, L. M., Acevedo, B., Grenard, J. L., \& Botvin, G. J. (2012). Long-term effects of self-control on alcohol use and sexual behavior among urban minority young women. International Journal of Environmental Research and Public Health, 9(1), 1-23. https://doi.org/10.3390/ijerph9010001

Hamama, L., \& Ronen-Shenhav, A. (2012). Selfcontrol, social support, and aggression among adolescents in divorced and twoparent families. Children and Youth
Services Review, 34(5), 1042-1049. https://doi.org/10.1016/j.childyouth.2012.0 2.009

Hardoni, Y., Neherta, M., \& Sarfika, R. (2019). Reducing aggressive behavior of adolescent with using the aggression replacement training. Jurnal Endurance: Kajian Ilmiah Problema Kesehatan, 4(3), 488-495. https://doi.org/10.22216/jen.v4i3.4587

Hastuti, L. W. (2018). Kontrol diri dan agresi: Tinjauan meta-analisis. Buletin Psikologi, 26(1), 42-53. https://doi.org/10.22146/buletinpsikologi.3 2805

Heatherton, T. F., \& Wagner, D. D. (2011). Cognitive neuroscience of self-regulation failure. Trends in Cognitive Sciences, 15(3), 132-139. https://doi.org/10.1016/j.tics.2010.12.005

Hofmann, W., \& Kotabe, H. (2012). A general model of preventive and interventive selfcontrol. Social and Personality Psychology Compass, 6(10), 707-722. https://doi.org/10.1111/j.17519004.2012.00461.x

Hofmann, W., Luhmann, M., Fisher, R. R., Vohs, K. D., \& Baumeister, R. F. (2014). Yes, But Are They Happy? Effects of Trait SelfControl on Affective Well-Being and Life Satisfaction. Journal of Personality, 82(4), 265-277.

https://doi.org/10.1111/jopy.12050

James, L. R., \& LeBreton, J. M. (2010). Assessing aggression using conditional reasoning. Current Directions in Psychological Science, 19(1), 30-35. https://doi.org/10.1177/096372140935927 9

Job, V., Friese, M., \& Bernecker, K. (2015). Effects of practicing self-control on academic performance. Motivation Science, 1(4),

219-232. https://doi.org/10.1037/mot0000024

Jones, A., Lemma, L. C. G. Di, Robinson, E., Christiansen, P., Sarah Nolan, TudurSmith, C., \& Field, M. (2016). Inhibitory control training for appetitive behaviour change: A meta-analytic investigation of mechanisms of action and moderators of effectiveness. In Appetite (Vol. 97, Issue 97, pp. $16-28)$ https://doi.org/10.1016/j.appet.2015.11.013 
Jones, C. N., Hart, S. R., Jimerson, S. R., Dowdy, E., Earhart, J., Renshaw, T. L., Eklund, K., \& Anderson, D. (2009). Solution-focused brief counseling: Guidelines, considerations, and implications for school psychologists. The California School Psychologist, 14(1), 111-122. https://doi.org/10.1007/BF03340957

Kuhnle, C., Hofer, M., \& Kilian, B. (2011). The relationship of self-control, procrastination, motivational interference and regret with school grades and life balance. Diskurs Kindheits-Und Jugendforschung, 6(1), 3144.

https://doi.org/10.3224/diskurs.v6i1.4943

Lawrence, C. (2006). Measuring individual responses to aggression-triggering events: development of the situational triggers of aggressive responses (STAR) scale. Aggressive Behavior, 32(3), 241-252. https://doi.org/10.1002/ab.20122

Magen, E., \& Gross, J. J. (2010). Getting our act together: Toward a general model of selfcontrol. In R. Hassin, K. Ochsner, \& Y. Trope (Eds.), Self Control in Society, Mind, and Brain (pp. 335-353). Oxford University Press. https://doi.org/10.1093/acprof:oso/978019 5391381.003.0018

Manuel Sofia, R., \& Cruz, J. F. A. (2015). Selfcontrol as a mechanism for controlling aggression: A study in the context of sport competition. Personality and Individual Differences, $\quad 87, \quad 302-306$. https://doi.org/10.1016/j.paid.2015.08.025

Miles, E., Sheeran, P., Baird, H., Macdonald, I., Webb, T. L., \& Harris, P. R. (2016). Does self-control improve with practice? Evidence from a six-week training program. Journal of Experimental Psychology: General, 145(8), 1075-1091. https://doi.org/10.1037/xge0000185

Miranda, A., \& Presentacion, M. J. (2000). Efficacy of cognitive-behavioral therapy in the treatment of children with adhd, with and without aggressiveness. Psychology in the Schools, 37(2), 169-182. https://doi.org/10.1002/(SICI)15206807(200003)37:2<169::AIDPITS8>3.0.CO;2-8

Murray, A. L., Obsuth, I., Eisner, M., \& Ribeaud, D. (2016). Shaping aggressive personality in adolescence: Exploring cross-lagged relations between aggressive thoughts, aggressive behaviour and self-control. Personality and Individual Differences, 97, 1-7.

https://doi.org/10.1016/j.paid.2016.03.022

Peterson, C., \& Seligman, M. E. P. (2004). Character strengths and virtues: A handbook and classification. Oxford University Press.

Piquero, A. R., Jennings, W. G., Farrington, D. P., Diamond, B., \& Gonzalez, J. M. R. (2016). A meta-analysis update on the effectiveness of early self-control improvement programs to improve selfcontrol and reduce delinquency. Journal of Experimental Criminology, 12(2), 249264. https://doi.org/10.1007/s11292-0169257-z

Putri, D. A., Saputra, W. N. E., Hartanto, D., \& Nugraha, A. (2019). The effectiveness of solution focused brief counseling (SFBC) based on creative art to reduce students social aggressive behaviour. Nusantara of Research: Jurnal Hasil-Hasil Penelitian Universitas Nusantara PGRI Kediri, 6(2), 60-67.

https://doi.org/10.29407/nor.v6i2.13616

Rahman, A. A. (2014). Psikologi sosial: Integritas pengetahuan wahyu dan pengetahuan empirik. Rajawali Pers. https://opac.perpusnas.go.id/DetailOpac.as px?id=858160\#

Restu, Y., Yusri, Y., \& Ardi, Z. (2013). Studi tentang perilaku agresif siswa di sekolah. Konselor, 2(1). https://doi.org/10.24036/02013211074-000

Ridder, D. T. D. de, Lensvelt-Mulders, G., Finkenauer, C., Stok, F. M., \& Baumeister, R. F. (2012). Taking stock of self-control: A meta-analysis of how trait self-control relates to wide range of behaviors. Personality and Social Psychology Review, 16(1), 76-99. https://doi.org/10.1177/108886831141874 9

Salmi, -. (2015). Perilaku agresif dan penanganannya (studi kasus pada siswa SMP negeri 8 Makassar). Jurnal Psikologi Pendidikan Dan Konseling: Jurnal Kajian Psikologi Pendidikan Dan Bimbingan Konseling, 1(1). https://doi.org/10.26858/jpkk.v1i1.1357 
Tucker, C. J., Van Gundy, K. T., Wiesen-Martin, D., Hiley Sharp, E., Rebellon, C. J., \& Stracuzzi, N. F. (2014). Proactive and reactive sibling aggression and adjustment in adolescence. Journal of Interpersonal Violence, 30(6), 965-987. https://doi.org/10.1177/088626051453976 0

Wiretna, C. D., \& Saputra, W. N. E. (2020). Keefektifan konseling ringkas berfokus solusi untuk mereduksi perilaku online aggression. Jurnal Pendidikan: Teori Dan Praktik, 5(2), 19-23. https://doi.org/https://doi.org/10.26740/jp.v 5n2.p19-23

Yusainy, C., \& Lawrence, C. (2020). Provoked aggression: An interplay between selfcontrol training, mindfulness induction, and provocation sensitivity. Journal of Aggression, Maltreatment \& Trauma, 29(5), 628-642. https://doi.org/10.1080/10926771.2019.17 09595

Zahrani, Z., \& Ambarini, T. K. (2019). Pelatihan kontrol diri untuk menurunkan perilaku agresif siswa. ANALITIKA, 11(2), 104. https://doi.org/10.31289/analitika.v11i2.27 98 